\title{
Dayanıklılık Gerektiren Sporlarda GAPPB1 rs7181866 Polimorfizminin Etkisi
}

\author{
Effect of GAPPB1 rs7181866 Polymorphism in Sports Requiring \\ Endurance
}

\author{
Özlem Özge YILMAZ \\ Tolga POLAT ${ }^{* *}$ \\ Korkut ULUCAN ${ }^{* * *}$ (iD
}

Öz

Nükleer solunum faktörü 2, GA Bağlayıcı Protein Transkripsiyon Faktörü Alt Birimi Alfa (GABPA) ve GA Bağlayıcı Protein Transkripsiyon Faktörü Alt Birimi Beta 1 (GAPPB1) genleri tarafından sentez edilen polipeptidlerin oluşturduğu hücresel metabolizma için önemli bir solunum faktörüdür. NRF-2 proteininin, hücresel solunum kapasitesini ve egzersiz sırasında ATP üretim hızını arttırdığı bilinmektedir. Ek olarak NRF-1 ile koordineli bir şekilde çalışarak mitokondriyal biyogenezi indükler ve nükleo-mitokondriyal etkileşimlerde önemli bir rol oynar. Gen üzerinde bulunan fonksiyonel bir polimorfizm (rs7181866, G/A) proteinin çalışma mekanizmasını etkileyerek hücresel solunum metabolizmasında değişikliklere neden olmaktadır. Yapılan çalışmalar, sporcuların dayanıklılık özellikleri ile rs7181866 AA genotipi ve A alleli arasındaki ilişkiyi ortaya koymuştur. Bu derlemede, rs7181866 polimorfizmi ile ilgili gerçekleştirilmiş çalışmaları bir araya getirmeyi amaçladık.

Anahtar Kelimeler: Nükleer solunum faktörü, polimorfizm, dayanıklılık, spor genetiği

\begin{abstract}
Nuclear respiratory factor 2 is an important factor for cellular metabolism caused by polypeptides synthesized by the GA Binding Protein Transcription Factor Subunit Alpha (GABPA) and the GA Binding Protein Transcription Factor Subunit Betal (GAPPB1) genes. NRF-2 protein is known to increase cellular respiratory capacity and ATP production rate during exercise. In addition, in coordination with NRF-1, NRF-2 induces mitochondrial biogenesis and plays an important role in nucleo-mitochondrial interactions. A functional polymorphism lying on the gene (rs7181866, G/A) effects the protein's activity,

* Yüksek lisans Öğrenci, Üsküdar Üniversitesi, Mühendislik ve Doğa Bilimleri Fakültesi, Moleküler Biyoloji ve Genetik Bölümü, İstanbul, Türkiye, ozlem.ozge.yilmaz97@gmail.com

* Yüksek lisans Öğrenci, Üsküdar Üniversitesi, Mühendislik ve Doğa Bilimleri Fakültesi, Moleküler Biyoloji ve Genetik Bölümü, İstanbul, Türkiye. tolgapolat.mbg@gmail.com

*** Prof. Dr. Marmara Üniversitesi, Diş Hekimliği Fakültesi, Temel Tip Bilimleri, Tibbi Biyoloji ve Genetik Bölümü, İstanbul, Türkiye.korkut.ulucan@marmara.edu.tr
\end{abstract}


causing downregulation on cellular respiration metabolism. Studies have revealed the relationship between athlete's endurance properties and the rs7181866 AA genotype and A allele. In this review, we aimed to compose the findings of the results of rs7181866 polymorphism studies in endurance athletes.

Keywords: Nuclear respiratory factor, polymorphism, endurance, sport genetics

\section{GİRIș}

İnsan Genom Projesi, 20-25 bin civarında olduğu tahmin edilen genlerimizin yapısının, görevlerinin ve biyolojik sistemlerimize olan etkilerinin belirlenmesini sağlamıştır. Bu biyolojik sistemlerin başında da atletik performansa etki eden gerek fizyolojik gerek biyokimyasal ve gerekse psikolojik faktörler gelmektedir (Çorak ve ark., 2017). Atletik performans, bireyin doğasında var olan genetik yapının ve çevresel faktörlerin ortak bir kombinasyonudur ve bireysel özelliklerimizin birçoğunun (dayanıklılık, kas koordinasyonu, güç, motivasyon vb.) genetik altyapıya sahip olduğu bilinmektedir (Sipahi ve ark., 2018; Konuk, 2017). Düzenli antrenmanlarla genetik faktörlerin gelişimi atletik performansın oluşmasına ve gelişmesine katkıda bulunur (Ulucan ve ark., 2015). Gelişen biyoinformatik biliminin katkıları ile sadece DNA düzeyinde değil, RNA düzeyinde de atletik performans ile ilişkili birçok biyobelirteç belirlenmiştir (Altuntaş ve ark., 2020).

Fiziksel özelliklerimiz, genetik olarak bizlerde kodlanan ve antrenman, beslenme ve programlı yaşam ile birbirleri arasında değişim gösterebilen kas liflerimiz tarafından belirlenmektedir. İki farklı kas lifi bulunmaktadır; Tip I (yavaş kasılan kas lifi) ve Tip II (hızlı kasılan kas lifi). Tip I kas lifi Tip II kas lifine göre daha uzun süre kasılıp-gevşeme işlevlerini sürdürebilir. Bu lifler, aerobik enerji sisteminin daha baskın görünmesinden dolayı uzun mesafeli koşu, yüzme gibi dayanıklılık aktiviteleri ile ilişkilidir. Tip II kas lifleri kendi içinde Tip II $_{\mathrm{A}}$ ve Tip $\mathrm{II}_{\mathrm{B}}$ olarak ayrıllı. Tip $\mathrm{II}_{\mathrm{A}}$ kas lifleri aerobik ve anerobik metabolik yolakları kullanırken Tip I $_{\mathrm{B}}$ kas lifleri anaerobik metabolizmayı kullanarak hızlı bir şekilde kasılıp-gevşeme özelliklerini gerçekleștirirler (Greenemeier, 2012).

Yaşa bağlı olarak da iskelet kas lifi kompozisyonunda değişiklikler meydana gelmektedir. Yaşlanma ile beraber Tip $\mathrm{II}_{\mathrm{B}}$ kas lifi oranı azalır ve daha yavaş kontraksiyon yapan Tip $\mathrm{II}_{\mathrm{X}}$ isoform oranı artar (Suzuki ve ark., 2002). Aerobik antrenmanlarla Tip II'den Tip I’e, anaerobik antrenmanlarla da Tip I'den Tip II'ye dönüşümlerin olabileceği yapılan çalışmalar ile belirtilmiştir. Ancak, bu değişimin oranı sadece \%1-2 oranındadır. Yüksek eşikli motor ünitelerin aktivasyonu ve antrenman ile Tip $\mathrm{II}_{\mathrm{B}}$ kas fibrillerinin, miyozin ATP eş-biçimli içeriklerini biyokimyasal olarak değiştirerek Tip $\mathrm{II}_{\mathrm{A}}$ kas fibrillerine dönüştükleri bildirilmiştir (Zülküf ve ark., 2010).

Nükleer solunum faktörü 2, GA Bağlayıcı Protein Transkripsiyon Faktörü Alt Birimi Alfa (GABPA) ve GA Bağlayıcı Protein Transkripsiyon Faktörü Alt Birimi Beta 1 (GAPPB1) genleri tarafından sentez edilen alt ünitelerinden oluşmaktadır. NRF-2 proteininin hücresel solunum kapasitesini ve egzersiz sırasında ATP üretim hızını arttırdığı düşünülmektedir (Pokrywka ve ark., 2016). NRF2, NRF-1 ile koordineli bir şekilde çalışarak mitokondriyal biyogenezi indükler ve nükleomitokondriyal etkileşimlerde önemli bir rol oynar. NRF-2 proteini iki gen tarafından kodlanan beş alt birimden $(\alpha, \beta 1, \beta 2, \gamma 1, \gamma 2)$ oluşmaktadır. $\alpha$ alt birimi 21q21.3'te lokalize olan $\alpha$ geni tarafından 
kodlanır. $\beta$ alt ünitesi ise $15 \mathrm{q} 21.29$ 'da lokalize olan $\beta$ geni tarafından kodlanır (Bouchard ve ark., 2000). NRF-2 proteini, fiziksel egzersize yanıt olarak maksimum oksijen tüketimi $\left(\mathrm{VO}_{2 \max }\right)$ ile ilişkili olduğu bildirilmiştir (Eynon ve ark., 2009). rs031031 (intron4, C/T), rs12594956 (intron3, A/C) ve rs7181866 (intron3, A/G) olmak üzere üç farklı polimorfizm ön plana çımaktadır. $\mathrm{VO}_{2 \max }$ ile en fazla ilişkilendirilmiş polimorfizm rs7181866 polimorfizmidir (MacIejewska-Karloeska ve ark., 2012). Günümüze kadar yapılan çalısmalar bu spesifik polimorfizmlerin dayanıklılık performansı ile ilişkili olabileceğini düşündürmektedir.

Bu derlememizde dayanıklılık özelliği ile ilişkili rs7181866 polimorfizminin literatür taramasını gerçekleştirip, derlememize dahil edilen çalışmalar ile karşılaştırılmasını amaçladık.

\section{LITERATÜR TARAMASI}

Literatür taramasını Google Akademik ve PUBMED veri tabanlarında "spor, sporcu, genetik, NRF2, spor genetiği, polimorfizm" anahtar kelimeleri ve kombinasyonları ile taranmıştır. Çalışmamıza rs7181866 bölgesinin polimorfizm dağılımları içeren yayınlar dahil edilmiştir.

\section{BULGULAR}

Yapılan literatür taramasında kriterlerimize uygun 3 adet çalışma bulunmuş ve değerlendirmeye alınmıştır. Eynon ve ark. (2009) yaptığı çalışmada 155 sporcu ve 240 gönüllü bireyi çalışmalarına dahil etmiş ve GAPPB1 rs7181866 polimorfizmini incelemiştir. Kohortunun 74’ü (\%48) dayanıklılık ve 81'i (\%52) sprinter sporculardan oluşmuş, sporcuların 145'inin AA (\%94), 10'unun (\%6) ise AG genotipinde olduğu belirtilmiştir. Kohortunda GG genotipinde herhangi bir sporcuya rastlamamışlardır. Allel sayı ve yüzdeleri ise, A ve G sırasıyla, 300 (\%97) ve 10 (\%3)'dur. Dayanıklılık sporcularında AA ve AG genotipleri için sayı ve yüzdeleri sırasıyla 65 (\%88) ve 9 (\%12) olarak belirtilmiştir ve GG genotipinde hiçbir sporcuya rastlanmamıştır. Sprinter sporcuları için AA ve AG genotipleri için ilgili sayı ve yüzdeleri sırasıyla 80 (\%99) ve 1 (\%1) olarak belirtilmiştir ve bu sporcularda da GG genotipine rastlanmamıştır. Allel sayılarına bakıldı̆̆ında $G$ alleli dayanıklılık sporcuları için 9 (\%6), sprinter sporcuları için 1 (\%1) bulunmuştur. A alleli için ilgili sayılar ve yüzdeler, dayanıklılık sporcuları için 139 (\%94) ve sprinter sporcuları için 161 (\%99) bulunmuștur.

Maciejewska-Karłowska ve ark. (2012) yaptıkları çalışmada 55 Polonyalı erkek kürekçiyi (30’u elit, 25 ’i profesyonel) ve 130 gönüllü bireyi GAPPB1 rs7181866 bakımından analiz etmişlerdir. Kontrol grubu ile sporcu grubunu karşılaştırdıklarında genotip dağılımı bakımından ilk grup arasında istatistiksel olarak anlamlı bir fark olduğunu bildirmişlerdir. Tüm kürekçilerin 49'unun (\%89) AA genotipinde, 6’sının (\%11) ise AG genotipinde oldukları bildirilmiştir. Yazarlar Polonyalı kürekçi grubundaki sporcularda GG genotipine rastlamadıklarını belirtmiştir. Allel sayılarına bakıldığında A ve G allellerinin sayı ve yüzdeleri sırasıyla 104 (\%95) ve 6 (\%5)'dir. Elit kürekçiler için AA ve AG 
genotipleri için ilgili sayı ve yüzdeler sırasıyla 27 (\%90) ve 3 (\%10)'dür. Elit olmayan kürekçiler için AA ve AG genotipleri için sayı ve yüzdeler sırasıyla 22 (\%88) ve 3 (\%12) olarak belirtilmiştir. Allelik dağılımlarına bakıldığında G alleli elit kürekçiler için 3 (\%5), elit olmayan kürekçiler için de aynı şekilde 3 (\%6) olarak belirtilmiştir. A alleli için ilgili sayılar ve yüzdeler, elit kürekçiler için 57 (\%95) ve elit olmayan kürekçiler için 47 (\%94) olarak bulunmuştur.

Eynon ve ark. (2012) yaptıkları çalışmada 89 dayanıklılık sporcusu (19 uzun mesafe koşucusu, 32 profesyonel yol bisikletçisi ve 38 kürekçi), 38 elit erkek atlet ve 110 sağlıklı sedanter erkek bireyi aynı polimorfizm bakımından analiz etmiştir. Yapılan genotipleme sonucunda sporcuların 122'sinin AA (\%96) ve 5’inin (\%4) AG genotipinde olduğu belirtilmiştir. Bu çalışmada GG genotipine rastlanmamıştır. Allel sayı ve yüzdeleri ise, A ve G sırasıyla, 249 (\%98) ve 5 (\%2) olarak belirtilmiştir.

Dayanıklılık sporcularında AA ve AG genotipleri için sayı ve yüzdeleri 86 (\%97) ve 3 (\%3) olarak belirtilmişken, sprinter sporcuları için sırasıyla 36 (\%95) ve 2 (\%5) olarak belirtilmiştir. Allel sayılarına bakıldığında $\mathrm{G}$ alleli dayanıklılık sporcuları için 3 (\%2), sprinter sporcuları için 2 (\%3) bulunmuştur. A alleli için ilgili sayılar ve yüzdeler, dayanıklılık sporcuları için 175 (\%98) ve sprinter sporcuları için 74 (\%97) bulunmuştur.

Çalışmamıza dahil ettiğimiz 3 çalışmaya ait genotip ve allelik dağılım verileri Tablo 1 ve 2'de özetlenmiştir.

Tablo 1. Derlememize dahil edilen çalışmalardaki sporcuların genotipik dağılımları.

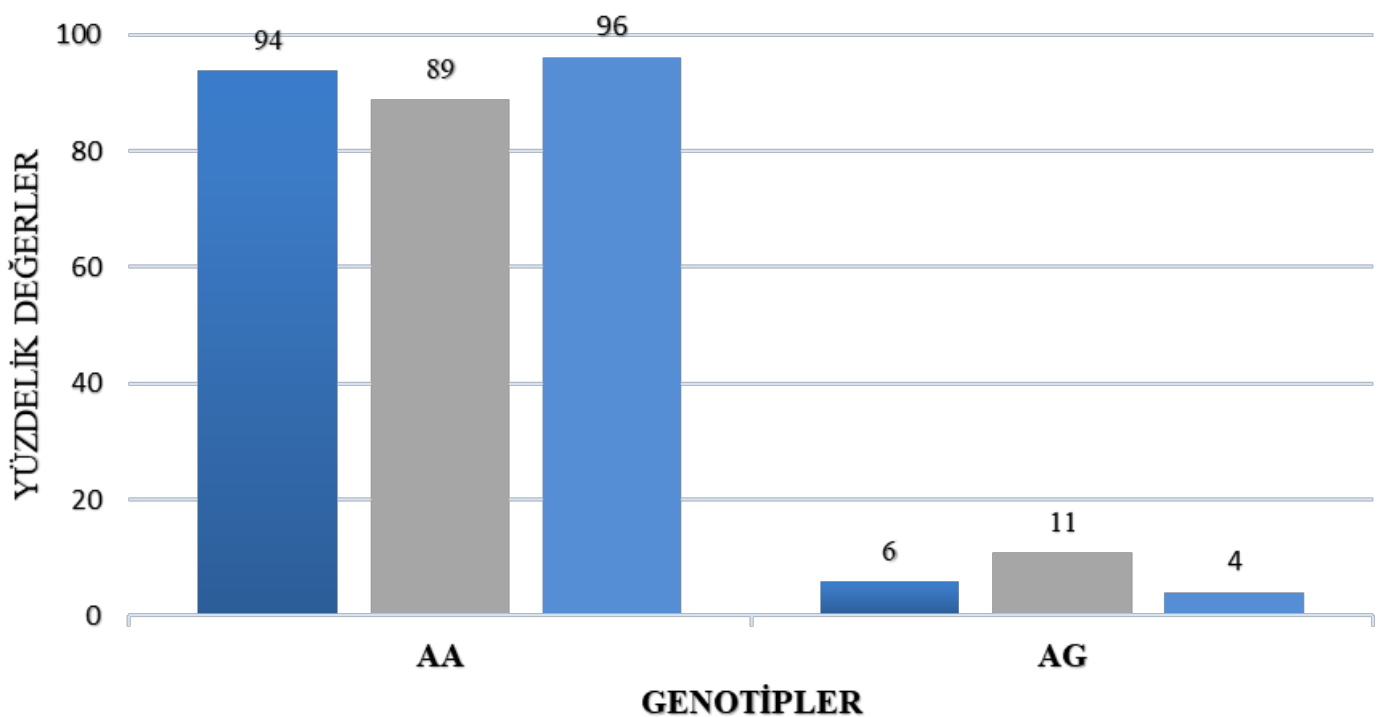

•Eynon ve ark., 2009 - Karlowska ve ark., 2012 —Eynon ve ark., 2012 
Tablo 2. Derlememize dahil edilen çalışmalardaki sporcuların allelik dağılımları.

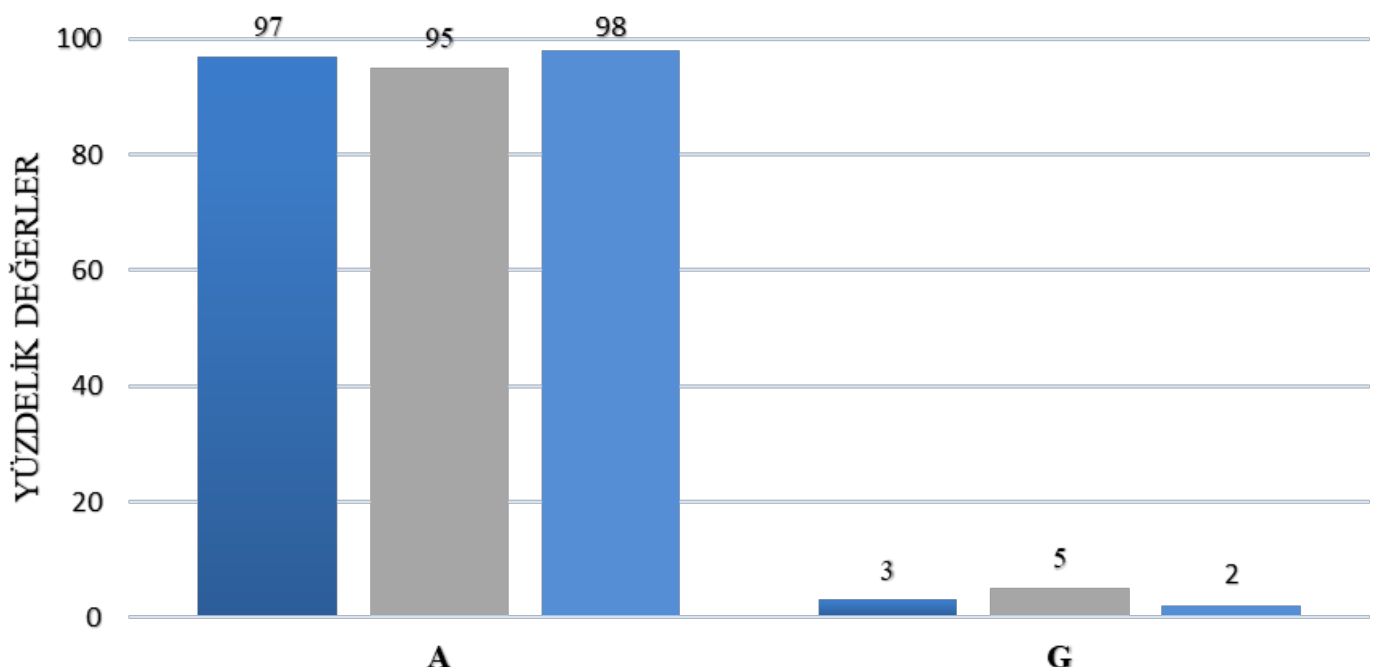

ALLELLER

-Eynon ve ark., 2009 Karlowska ve ark., 2012 Eynon ve ark., 2012

\section{SONUÇ}

Yapılan çalışmalar, atletik performansın oluşumunu ve gelişimini, çevresel faktörler ve farklı gen gruplarının etkileşimi ile belirlendiğini göstermiştir(Ulucan, 2016). Atletik performans multifaktöryel (birçok gen ailesi ve çevresel faktörlerin etkileşimi ile oluşan özellikler) bir özelliktir; 20'den fazla polimorfizm elit dayanıklılık performansı ile ilişkilendirilmiştir (MacIejewska-Karłowska ve ark., 2012). NRF-2 proteini, çeşitli mitokondriyal enzimleri kodlayan nükleer genlerin üzerinde etkili rol oynaması nedeniyle, egzersiz sırasında solunum kapasitesinin ve ATP üretim hızının artmasına katkıda bulunur. Bu özelliğinden dolayı spor bilimciler tarafından dayanıklılık özelliğinin genetik bir belirteci olarak dikkate alınmıştır.

Dayanıklılık sporcularında GAPPB1 rs7181866 polimorfizmleri incelendiğinde AA genotipinin ve A allelinin diğer genotip ve allele göre daha baskın olduğu görülmüştür. Çalışmalara farklı popülasyondan bireylerin dahil edildiği göz önüne alındığında GAPPB1 rs7181866 polimorfizminin özellikle dayanıklılık sporcularında atletik performansa genel bir yatkınlık sağladığını söyleyebiliriz.

GAPPB1 rs7181866 polimorfizminin bu denli yüksek etkisi olmasına rağmen literatürde bu polimorfizm ile ilgili yeteri kadar çalışma bulunmamaktadır. Farklı popülasyon ve sporcu grupları üzerinde yapılacak çalışmalar ile genin etkisinin daha da netlik kazanacağ1 düşünülmektedir. Bu derlememizin spor genetiği ve GAPPB1 rs7181866 polimorfizminin analizini kapsayacak yapılacak sonraki çalışmalar için önemli bir kaynak olacağı inancındayız. 


\section{KAYNAKLAR}

Akçaml, D., Sipahi, S., Yüksel, İ., Kavas, N. C. (2018). Futbolcularda Peroksizom Proliferatör - Aktive Reseptör Alfa rs4253778 Polimorfizm Dağılımının Belirlenmesi. Eurasian Research in Sport Science. 3(2): 75-79.

Altuntaş, İ., Polat, T., Ulucan, K., (2020). MikroRNA'ların Atletik Performansa Etkisi Effect of MicroRNAs on Athletic Performance. Eurasian Research in Sport Science. 103-109.

Bouchard, C., Rankinen, T., Chagnon, Y.C. (2000). Genomic scan for maximal oxygen uptake and its response to training in the Heritage Family Study. J Appl Physiol. 88: 551-559.

Çorak, A., Kapıc1, S., Sercan, C. (2017). A pilot study for determination of anxiety related SLC6A4 promoter "S "S" and "L" alleles in healthy Turkish athletes. Cellular and Molecular Biology. 63(5): 29-31.

Eynon, N., Ruiz, J.R., Bishop, D.J. (2013). The rs 12594956 polymorphism in the NRF-2 gene is associated with top-level Spanish athlete's performance status. Journal of Science and Medicine in Sport.; 16(2): 135-139.

Eynon, N., Sagiv, M., Meckel, Y. (2009). NRF2 intron 3 A/G polymorphism is associated with endurance athletes' status. Journal of Applied Physiology. 107(1): 76-79.

Greenemeier L. (2012).Unnatural Selection: Muscle, Genes and Genetic Cheats. Scientific American.

Kaman, T., Kapıcı, S., Sercan, C., Konuk, M., Ulucan, K.Türk (2017). Milli Bisikletçilerde Alfa - Aktinin-3 R577X Polimorfizm The Determination of Alpha-Actinin-3 R577X Polymorphisms Distribution in Turkish National Cyclists. Marmara Üniversitesi Spor Bilimleri Dergisi. 41-47.

Maclejewska-Karłowska, A., Leońska-Duniec, A., Ciszczyk, P. (2012). The GABPB1 gene A/G polymorphism in polish rowers. Journal of Human Kinetics. 31(1): 115-120.

Pokrywka, A., Kaliszewski, P, Majorczyk, E. (2013). Genes in sport and doping. Biology of Sport. 30(3): 155-161.

Suzuki, T., Connor, N.P., Lee, K. (2002). Age-related alterations in myosin heavy chain isoforms in rat intrinsic laryngeal muscles. Ann Otol Rhinol Laryngol. 111:962-7.

Ulucan K. (2016). Literature Review of Turkish Sportsmen in Terms of ACTN3 R577X Polymorphism. Clinical and Experimental Health Sciences. 6(1): 44-47.

Zülküf, T. (2010). A'dan Z’ye Vücut Geliștirme ve Fitness Ansiklopedisi. Ben Yazarım Yayınları. 